\title{
IL2 wt Allele
}

National Cancer Institute

\section{Source}

National Cancer Institute. IL2 wt Allele. NCI Thesaurus. Code C50934.

Human IL2 wild-type allele is located within 4q26-q27 and is approximately $5 \mathrm{~kb}$ in length. This allele, which encodes interleukin- 2 protein, plays a role in the proliferation of $\mathrm{T}$ and $\mathrm{B}$ lymphocytes. IL2 also has a putative role in immune responses to antigenic stimuli. Further, the expression of this gene in mature thymocytes is monoallelic, which represents an unusual regulatory mode for controlling the precise expression of a single gene. 